\title{
Kam C. Wong: One country two systems: cross-border crime between Hong Kong and China
}

\author{
Transaction Publishers: New Brunswick (U.S.A.) and London \\ (U.K.), 2012, ISBN: 978-1-4128-4623-3, 260 pages, \$39.95, \\ $£ 30,95, \$ C 47.95$
}

\section{Chuen Tien Nadine Chen}

Published online: 9 October 2012

(C) The Author(s) 2012. This article is published with open access at Springerlink.com

The curtains closed on Hong Kong's legendary gang boss "Big Spender" in 1998 when the Guangzhou Higher People's Court confirmed his guilt in masterminding the most notorious kidnappings Hong Kong had ever seen. Coming after a series of incidents that roused public concern over the erosion of the rule of law following the return of Hong Kong to China in 1997, the case was the first case to test Hong Kong's legal autonomy since the Handover. Kam C. Wong had a front row seat to the negotiations between the British and Chinese governments over the transfer when he was a public law lecturer at the Chinese University of Hong Kong. Later, as the Director of Chinese Law Program of the University, Wong became involved in the "Big Spender" case as it was the first time a Hong Kong legal resident was prosecuted, tried, and executed in China under the PRC Criminal Law for criminal conduct perpetrated largely in Hong Kong. With the eye of an insider, mind of a professional (both as a legal intellectual and consultant of the Hong Kong Police), and heart of a Hong Kong permanent resident, in One Country Two Systems: Cross-Border Crime between Hong Kong and China, Wong addresses legal and policy questions that arise when two Chinese jurisdictions clash, namely, how to resolve the conflict between Article 6 of the PRC Criminal Law (which allows the prosecution of criminal conduct committed outside of China in the PRC courts) and Article 19 of the Basic Law (which gives Hong Kong courts jurisdiction over all cases in the Region), and whether Hong Kong should have asked for extradition of "Big Spender" notwithstanding the absence of victims' reports and the PRC's concurrent jurisdiction claim.

With modern advances in communication, transportation and business structure, "national borders are becoming increasingly obsolete and irrelevant to criminal activities." The growth of commercial activities and ease of travel between

\footnotetext{
${ }^{1}$ KAM C. WONG, ONE COUNTRY TWO SYSTEMS: CROSS-BORDER CRIME BETWEEN HONG KONG AND CHINA 171 (2012) (citing Brian Tkhuck and Yvon Dandurand, "Recent International Efforts to Address Transnational Crime," Paper Presented at the International Converence on Crime and Criminal Justice in a Borderless Era, Ritsumeican University, Kyoto, Japan, November 2, 1998, 2).

C. T. N. Chen $(\bowtie)$

Duke University, Durham, NC, USA

e-mail: nadine.chen@duke.edu
} 
Mainland China and Hong Kong in particular contributed to the explosion of crossborder crimes. ${ }^{2}$ The HKSAR and the PRC have shared criminal intelligence and mutually assisted in criminal investigations through INTERPOL since 1987, but no formal judicial assistance agreement has ever been reached. Overall, PRC-HKSAR cooperation regarding cross-border crimes has been a healthy dialog, but in cases of repatriation it has always been from the PRC to the HKSAR. ${ }^{3}$ The Basic Law, Hong Kong's mini-Constitution, fails to address the problem of jurisdictional conflict. Legislative history shows that the drafters were aware of that but chose not to resolve it. $^{4}$ It therefore appears that in cases involving concurrent jurisdictional claims between the PRC and the HKSAR, the question boils down to "how much autonomy is the HKSAR willing to give up in return for more order and security for both places?"5 Wong is of the view that Hong Kong's insistence on total political independence or mutually exclusive legal jurisdiction will only lead to a zero-sum game. ${ }^{6}$

The book can be divided into two sections: The first, which takes up about twothirds of the book, is largely factual and benefits from a richly descriptive narrative. Following an introduction on the significance of the case in Chapter One, Chapter Two is an artfully written account of "Big Spender" i.e. Cheung Tse-keung's background and criminal career and the investigation, prosecution and adjudication of his case. Chapter Three gives a general overview of the PRC criminal justice process with reference to Cheung's case, and a discussion of each stage of his trial. Chapter Four outlines the debate in Hong Kong over Cheung's case, and Chapter Five provides a brief historical account of the PRC-HKSAR cross-border police operations and judicial assistance negotiations. The second part of the book starts with a legal analysis of the positions held by the PRC and the HKSAR as informed by existing scholarship, as well as the author's analysis of applicable Chinese, British, Hong Kong and international law bearing on the disposition of the case, which add up to support his thesis presented in Chapter Seven, which is that questions of cross-border crime should be approached as a debate over policy and politics and not law. The book ends with Chapter Eight, where Wong presents his final reflections, surmising that the case was decided on politics, culture and feelings rather than law and rationality.

Throughout the book, Wong is consistently mindful of the broader historical and sociopolitical context. He points out that while political elites shaped the debate as a challenge to the legal autonomy of Hong Kong, the manner in which the case was handled revealed that "neither the Hong Kong justice officials (as agents of legal institutions) nor the general public (as the embodiment of legal culture) showed much appreciation for the 'letter' and 'spirit' of the rule of law."7 For example, not a single justice official suggested that Hong Kong had the right to try the part of the case in which the PRC court had no jurisdiction, thereby stripping from the PRC the opportunity to entertain such a request. ${ }^{8}$ Hong Kong's law enforcement officials were less interested in enforcing the law than protecting the privacy of the rich kidnapping

\footnotetext{
${ }^{2}$ Id., 171.

${ }^{3} I d$., 126.

${ }^{4} I d ., 143$.

${ }^{5}$ Id., 172.

${ }^{6}$ Id., 171.

${ }^{7}$ Id., 195.

${ }^{8}$ Id., 199.
} 
victims, and less interested in defending Hong Kong people's rights than using law to justify cases tried in China for political or policy reasons. ${ }^{9}$ And while the legal and political elites asked for the return of the case to Hong Kong in the name of the public, surveys revealed that people on the streets were actually more concerned with achieving substantial, rather than procedural, justice, thereby condemning "Big Spender" to the possibility of a death sentence by Chinese courts before he was legally tried and convicted. ${ }^{10}$

The gross disparity in legal cultures brings out Wong's proposal that the dispute is in fact one over political identity, disguised as a conflict over legal rights. ${ }^{11}$ It is the cultural gap between Chinese common people and western-trained elites as to what law, order and justice mean that should be investigated and debated, and not so much the integrity of "one country, two systems." 12 Wong gives two reasons for why the debate cannot be resolved by a "correct interpretation and application of the Basic Law." First, the Basic Law was not meant to be interpreted with exactitude, but designed rather as a living constitutional document, making allowance for a yet-to-be formed PRC-HKSAR relationship. ${ }^{13}$ Second, the debate is one over interests and policy, not law, as cross-border criminal cases involve balancing autonomy with comity, and claims of criminal jurisdiction automatically implicate the proper exercise of police power to secure state interests. ${ }^{14}$ The majority of participants to the debate are thus wrong in adopting the rule of law approach for a resolution.

While Wong's conclusion that the issue is one of policy and not law may not be groundbreaking for conflicts in the realm of public international law, he does expose the oft neglected fact that the HKSAR and the PRC were never intended to be kept apart forever. The HKSAR, as the special administrative region, should have been a junior partner of the national effort to capture "Big Spender" for national interests when the order from the highest PRC political leadership came down. ${ }^{15}$ The ultimate objective of the "one country, two systems" formula is to bring the PRC and the HKSAR together, not to set them apart; it is to resolve conflicts, not to create divide. ${ }^{16}$ The "Big Spender" case, according to Wong, was thus one where national sovereignty trumps local autonomy, and collective interest in safety outweighs individual entitlements to legal process. ${ }^{17}$ In a political atmosphere where political elites and legal intellectuals, both local and abroad, tend to side with Hong Kong as if protecting David from a human-rights abusing Goliath, Wong's perspective that Hong Kong must look beyond the local impact of the case and strive for a settlement in line with the true spirit of "one country, two systems," which is the eventual reintegration with China, is a breath of fresh air. Moreover, the wealth of literature and other materials he used to formulate his perspective no doubt achieves his intention that the book be a "working-policy paper for deciding important legal

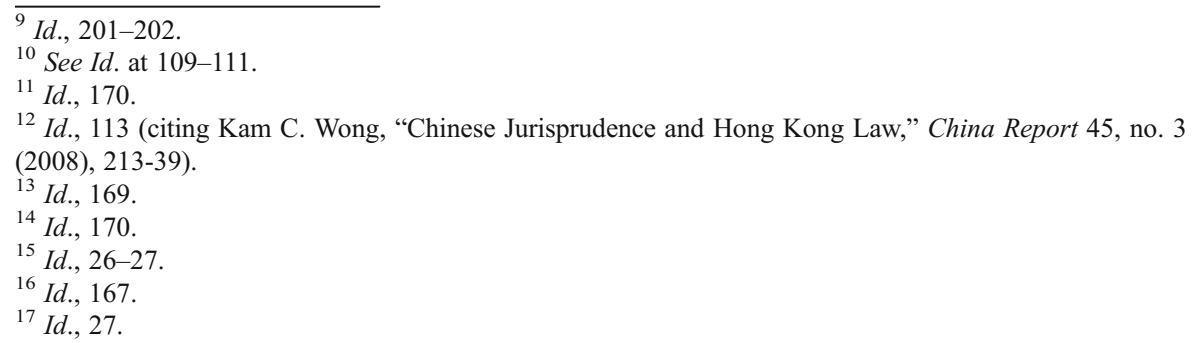


policy issues raised in the 'Big Spender' case" as well as an "academic treatise for scholars who want to understand cross-border crime and related jurisprudential issues." 18 Yet, because of the broad stroke of legal analysis employed, this book would likely appeal to the general reader as well.

Open Access This article is distributed under the terms of the Creative Commons Attribution License which permits any use, distribution, and reproduction in any medium, provided the original author(s) and the source are credited.

${ }^{18}$ Id., 4. 